\title{
Current and Potential Antiarrhythmic Drugs Targeting Voltage-Gated Cardiac Ion Channels
}

\author{
Mathew Perez-Neut, Vidhya Rao, Lauren Haar, Keith W Jones and Saverio Gentile*
}

Department of Molecular Pharmacology and Therapeutics, Loyola University Chicago, Maywood, IL USA

\begin{abstract}
Voltage-gated ion channels play a fundamental role in the generation and propagation of the cardiac action potential by acting synergistically to produce an ionic current across cellular membranes. Abnormalities of heart ion channel activities that lead to loss or gain of function (channelopathies) are often associated with disruption of the coordinated propagation of electrical activity of the cardiac myocytes and can generate fatal arrhythmogenesis. Drugs that act on cardiac ion channels have long been used to restore normal rhythm and conduction in patients affected by cardiac arrhythmias and offered to basic scientists the possibility to characterize distinct ion channel classes. This review will explore the mechanisms and role of the current anti-arrhythmic drugs used in the clinic, and discuss recent development on ion channel openers as potential anti-arrhythmic drugs.
\end{abstract}

Abbreviations: VGIC: Voltage gated ion channels; VGKC: Voltage gated potassium channels; KCNQ: Potassium Channel, Voltage-Gated, KQT-like subfamily; KCNH: Potassium channel voltage gated subfamily H; ATP: Adenosine tri phosphate; hERG1: human Ether-à-go-go-Related Gene; SCN: Sodium channel, voltage gated; CACNA: Calcium channel, voltage gated [gene]; CaV: Calcium channel, voltage gated [protein]; RyR: Ryanodine receptor

\section{Introduction}

Voltage-gated ion channels (VGIC) are pore forming transmembrane proteins which are ion permeable and gated by changes of transmembrane voltage [1]. Activities of VGIC are characterized by defined parameters ranging from distinct ion selectivity (e.g. $\mathrm{Na}^{+}$, $\mathrm{K}^{+}, \mathrm{Ca}^{2+}$ or $\mathrm{Cl}^{-}$) to ionic direction (inward or outward ionic flow; currents). Opening and closing of VGIC specifically expressed in cardiac myocytes generate and propagate the electric signal to shape the waveform of a cardiac action potential [2]. While there are some differences in the shape of action potentials among different cell types found in the myocardium, the myocyte action potential is composed by 5 phases (4-0-1-2-3) [3].

In the resting state, when the cardiac muscle is relaxed (diastole) the activity of several pumps and ion transporters including $\mathrm{Na}^{+} / \mathrm{K}^{+}$pumps [4], $\mathrm{Na}^{+} / \mathrm{Ca}^{2+}$ exchanger [5] and $\mathrm{K}^{+}$ion channels (inwardly rectifying) [6] accumulate ions in the cytoplasm against their electrochemical gradient. This results in the generation of a negative membrane potential that peaks around $-85 /-95 \mathrm{mV}$ (phase 4; resting membrane potential. The membrane potential at resting state is unstable and slowly depolarizes (moves towards positive values) due to the activity of a specific member of the $\mathrm{Na}^{+}$channel family ("funny" $\mathrm{Na}^{+}$channels) [7] through which sodium ions slowly cross the membrane $\left(\mathrm{Na}^{+}\right.$ currents) until the membrane potentials reach a value that activates the fast $\mathrm{Na}^{+}$channel [8]. Consequently, the rapid $\mathrm{Na}^{+}$entry quickly depolarizes the cell membrane (phase 0) reaching up to values of $+20 / 25 \mathrm{mV}$. At this membrane potential, the inactivation gate of the fast $\mathrm{Na}^{+}$channels closes (inactivated state) producing an impermeable channel that can re-open only when the membrane potential reaches the values at rest [9]. This phenomenon underlines the initiation of the refractory period during which the cardiac cell cannot elicit another action potential. However, although in the refractory period, random failure of inactivation can lead to generation of a small $\mathrm{Na}^{+}$current (late current, $\mathrm{I}_{\mathrm{NaL}}$ ) that appears to contribute minimally in shaping the action potential of a normal cardiac myocyte but may play an important role in a diseased heart [10-12].

Closing of the $\mathrm{Na}^{+}$channels in addition to the slow opening of $\mathrm{Cl}^{-}$(inward flow of negative charges) [13-15] and potassium channels (outward flow of positive charges) determines the initial descending deflection of the cardiac action potential (phase 1) [16]. This event is followed by a plateau (phase 2) in which an inward $\mathrm{Ca}^{2+}$ currents resulting from activation of L-type calcium channels [17-19] is balanced by an outward $\mathrm{K}^{+}$current upon activation of KCNQ and KCNH type potassium channels [16]. During this phase, cells accumulate $\mathrm{Ca}^{2+}$ that is used in conjunction with ATP during the activation of the contractile machinery (systole).

Finally, closure of the $\mathrm{Ca}^{2+}$ channels determines the initiation of repolarization that is progressively accelerated by the full activation of potassium channels such as the $\mathrm{KCNH}_{2}$ (hERG1) channels (phase 3) [16]. As the membrane potential repolarizes, several potassium channels close resulting in restoring the resting membrane potential. At this point, the funny $\mathrm{Na}^{+}$channels can re-open until a new phase 4 initiates.

Aberrant cardiac ion channel activities can often be associated with generation of an abnormal action potential that results in arrhythmias [20-23]. For example, malfunction of several ion channels including $\mathrm{Na}^{+}, \mathrm{K}^{+}$or $\mathrm{Cl}^{+}$channels can lead to a pathological retardation in the repolarization of the cardiac action potential. This phenomenon is detected as prolonged QT interval measured by electrocardiogram (Long QT Syndrome, LQT) [24], and is the lead culprit in polymorphic ventricular tachycardia-the classical arrhythmia (Table 1).

Antiarrhythmic drugs aim to abolish the electrophysiological

*Corresponding author: Saverio Gentile, Department of Molecular Pharmacology and Therapeutics, Loyola University Chicago, Maywood, IL USA, E-mail: sagentile@luc.edu

Received: April 15, 2015; Accepted: May 04, 2015; Published: May 10, 2015

Citation: Perez-Neut M, Rao V, Haar L, Jones KW, Gentile S (2015) Current and Potential Antiarrhythmic Drugs Targeting Voltage-Gated Cardiac lon Channels. Cardiol Pharmacol 4: 139. doi:10.4172/2329-6607.1000139

Copyright: (c) 2015 Perez-Neut M et al. This is an open-access article distributed under the terms of the Creative Commons Attribution License, which permits unrestricted use, distribution, and reproduction in any medium, provided the original author and source are credited. 
Citation: Perez-Neut M, Rao V, Haar L, Jones KW, Gentile S (2015) Current and Potential Antiarrhythmic Drugs Targeting Voltage-Gated Cardiac lon Channels. Cardiol Pharmacol 4: 139. doi:10.4172/2329-6607.1000139

mechanisms that are responsible for the cardiac arrhythmias. These drugs can exhibit diverse properties according to their effects on the targeted ion channels as they and can be channel blockers (ligands that block ionic flows), gating inhibitors (ligand that inhibit channel gating either by acting on ion channel activation or inactivation) or activators (ligands that activate ion channels by direct binding) $[25,26]$.

\section{Pharmacology of the Cardiac $\mathrm{Na}^{+}$Channel}

Nine genes in the human genome (SCN1A through SCN9A) encode for $\mathrm{Na}^{+}$channels a subunit proteins named $\mathrm{Na}_{\mathrm{v}} 1.1$ through $\mathrm{Na}_{\mathrm{v}} 1.9$ and $4 \beta$ subunits (SCN1B-SCN4B). Although mRNA for several $\mathrm{Na}_{\mathrm{v}}$ channels have been found in the human heart, the product of the SCNA5 gene, $\mathrm{Na}_{\mathrm{v}} 1.5$, is considered the main $\mathrm{Na}^{+}$channel that determines excitability and electrical conduction velocity in the cardiac myocytes. This conclusion is centered on the observation that mutations of the $\mathrm{Na}_{\mathrm{v}} 1.5$ channel that cause partial or complete loss of $\mathrm{Na}_{\mathrm{v}} 1.5$ activity can cause a delay of depolarization during phase 0 of the action potential [27-31]. This is hypothesized to occur by enhancing $\mathrm{I}_{\mathrm{NaL}}$, which can lead to an abnormal $\mathrm{Ca}^{2+}$ entry during phase 2 or phase 3 upon reactivation of $\mathrm{Ca}^{2+}$ channels that has been related to clinically relevant cardiac arrhythmias such as Brugada syndrome (Table 1) [3234] .

\section{$\mathrm{Na}_{\mathrm{v}} 1.5$ channel blockers}

Class I antiarrhythmic drugs (Vaughan-Williams Classification [35]) target the fast acting cardiac $\mathrm{Na}^{+}$channels during phase 0 . These drugs cause inhibition of membrane permeability to $\mathrm{Na}^{+}$by acting as $\mathrm{Na}^{+}$channel blockers, thereby decreasing rate/velocity/magnitude of the depolarization that occurs in phase 0 of the cardiac action potential [36]. Since activity of $\mathrm{Na}^{+}$channel determines the speed through which a cardiac action potential depolarizes inhibition of $\mathrm{Na}^{+}$channels is a common strategy used to correct disturbances of the heart rhythm in which the heart rate is abnormally increased (pathological tachycardia/ tachyarrhythmia). Members of the Class I antiarrhythmic drugs are divided into three different categories $(1 \mathrm{~A}, 1 \mathrm{~B}, 1 \mathrm{C})$ and are defined by the different degree of $\mathrm{Na}^{+}$channel blockage.

Procainamide or quinidine is Class IA antiarrhythmic drugs indicated for the treatment of sustained ventricular fibrillation. The effects of these $\mathrm{Na}^{+}$channel blockers is reduction of cell excitability by increasing the threshold for the rapid depolarization during phase 0 . Consequently, termination of the refractory period of the atria and ventricles is delayed. However, these drugs can also be pro-arrhythmic and are contraindicated by the presence of prolonged QT [37].

Lidocaine is one of the most commonly used class IB antiarrhythmic. This drug blocks $\mathrm{Na}^{+}$channel in the conduction system and in the muscle cells of the heart causing inhibition of spontaneous depolarization during diastole [38,39].

Flecainide and Propafenone are examples of class IC antiarrhythmic drugs approved for the treatment of ventricular arrhythmias [40-42]. The overall effects of these $\mathrm{Na}^{+}$channel blockers results in inhibition of electrical conduction in the whole heart that causes a reduction of action

\begin{tabular}{|c|c|c|c|c|}
\hline \multirow{2}{*}{ Arrhythmia } & \multirow{2}{*}{ Description } & \multicolumn{2}{|c|}{ Mutation } & \multirow{2}{*}{ Function } \\
\hline & & Protein & Gene & \\
\hline \multirow{8}{*}{ Brugada Syndrome } & $\begin{array}{c}\text {-Abnormal ECG } \\
\text {-increased sudden cardiac death }\end{array}$ & $\mathrm{Na}_{\mathrm{v}} 1.5$ & SCN5A & $\mathrm{Na}^{+}$Channel $\alpha$ subunit \\
\hline & & SCN1B & SCN1B & $\mathrm{Na}^{+}$Channel $\beta$ subunit \\
\hline & & $\mathrm{Na}_{\mathrm{v}} 1.8$ & SCN10A & $\mathrm{Na}^{+}$Channel $\alpha$ subunit \\
\hline & & NAD1 & GPD1L & Nav1.5 Accessory subunit \\
\hline & & CHF1 & HEY2 & Unknown \\
\hline & & $\mathrm{Ca}_{\mathrm{v}} 1.2$ & CACNA1C & $\mathrm{Ca}^{2+}$ Channel $\alpha$ subunit \\
\hline & & CACNB2 & CACNB2 & $\mathrm{Ca}^{2+}$ Channel $\beta$ subunit \\
\hline & & KCNE3 & KCNE3 & Kv4.3 Channel $\beta$ subunit \\
\hline $\begin{array}{l}\text { Long QT } \\
\text { Syndrome } \\
\text { (LQT) }\end{array}$ & $\begin{array}{l}\text { - Long QT interval, } \\
\text { - Normal heart rate, } \\
\text { - Normal heart structure }\end{array}$ & & & \\
\hline LQT1 & & $\mathrm{Kv} 7.1$ & KCNQ1 & $\mathrm{K}^{+}$channel $\alpha$ subunit \\
\hline LQT2 & & Kv11.1 & $\mathrm{KCNH} 2$ & $\mathrm{~K}^{+}$channel $\alpha$ subunit \\
\hline LQT3 & & $\mathrm{Na}_{\vee} 1.5$ & SCN5A & $\mathrm{Na}^{+}$Channel $\alpha$ subunit \\
\hline LQT4 & & Ankirin-B & ANK2 & Nav1.5 anchoring protein \\
\hline LQT5 & & MIRP & KCNE1 & Kv7.1 Channel $\beta$ subunit \\
\hline LQT6 & & MINK & KCNE2 & Kv11.1 Channel $\beta$ subunit \\
\hline LQT7 & & Kir2.1 & $\mathrm{KCNJ} 2$ & $\mathrm{~K}^{+}$channel $\alpha$ subunit \\
\hline LQT8 & & $\mathrm{Ca}_{\mathrm{v}} 1.2$ & CACNA1C & $\mathrm{Ca}^{2+}$ Channel $\alpha$ subunit \\
\hline LQT9 & & Caveolin 3 & CAV3 & Scaffolding protein \\
\hline LQT10 & & SCN4B & SCN4B & $\mathrm{Na}^{+}$Channel $\beta$ subunit \\
\hline LQT11 & & $\begin{array}{c}\text { A-Kinase } \\
\text { anchor protein }\end{array}$ & AKAP9 & Anchoring protein \\
\hline LQT12 & & A1-syntrophin & SNTA1 & Nav1.5 anchoring protein \\
\hline LQT13 & & Kir3.4 & KCNJ5 & $\begin{array}{c}\text { G protein-activated rectifier } \mathrm{K}^{+} \\
\text {channel (GIRK) }\end{array}$ \\
\hline \multirow{3}{*}{$\begin{array}{c}\text { Short QT } \\
\text { Syndrome (SQT) }\end{array}$} & $\begin{array}{l}\text { - Short QT interval, } \\
\text { - Normal heart rate, } \\
\text { - Normal heart structure }\end{array}$ & Kv11.1 & $\begin{array}{c}\mathrm{KCNH} 2 \\
\mathrm{ERG} 1\end{array}$ & $\mathrm{~K}^{+}$channel $\alpha$ subunit \\
\hline & & Kv7.1 & KCNQ1 & $\mathrm{K}^{+}$channel $\alpha$ subunit \\
\hline & & Kir2.1 & KCNJ2 & $\mathrm{K}^{+}$channel $\alpha$ subunit \\
\hline
\end{tabular}

Table:1 The classical Arrhythmia 
potential frequency without changes in action potential duration. This is most probably achieved by inhibition of the NaL currents more than its effects on peak currents. However, these drugs are mostly used in structurally normal hearts.

Binding of $\mathrm{Na}_{\mathrm{v}} 1.5$ blockers to the target are associated with the conductive status of the channel as their binding affinities strongly increase with opened or inactivated channels due to improved access to specific binding sites. Class I antiarrhythmic drugs bind $\mathrm{Na}_{\mathrm{v}} 1.5$ during depolarization of the phase 0 more than at resting membrane potentials. The clinical efficacy of a class I antiarrhythmic drugs is mostly related to its unbinding kinetics and the choice of treatment is strongly dependent from the heart condition [43]. For example, lidocaine presents a rapid binding and unbinding kinetics and it can be considered as a pure $\mathrm{I}_{\mathrm{Na}}$ blocker [44]. However, lidocaine is not very effective in suppressing atrial fibrillation (AF) In contrast flecainide or propafenone have a slower binding and unbinding kinetics for $\mathrm{Na}^{+}$ channels compared to lidocaine and it is clinically effective in restoring heart function during AF. In addition, these latter drugs can also inhibit other ion channels that are important for the development of a cardiac action potential.

\section{$\mathrm{Na}_{\mathrm{v}}$ channel activators}

More than one hundred mutations in the SCN5A gene have been described as the cause of a pathological inhibition of the $\mathrm{Na}_{\mathrm{v}} 1.5$ activity [27-31]. Therefore, therapeutic use of $\mathrm{Na}_{\mathrm{v}} 1.5$ openers appears to be the most logical step to improve cardiac performance in for example Brugada or LQT3 patients. Unfortunately, few cardiac $\mathrm{Na}^{+}$ion channel activators have been developed or discovered and very little is known about the therapeutic possibilities of such compounds.

One of the side effects of positive inotropic agents such as the sympathomimetic dobutamine, is related to appearance of ventricular arrhythmia. Interestingly, one study compared the effects of $\mathrm{Na}^{+}$ channel activator LY341311 to dobutamine and showed that LY341311 effectively counteracted heart failure prolongation of the QT interval or revealed evidence for arrhymogenicity [45].

Another compound, KB130015 [46], has the unique ability to act as a $\mathrm{Na}^{+}$channel activator in a dose dependent fashion. KB130015 inhibits the $\mathrm{Na}^{+}$ion channel inactivation phase, thereby causing the $\mathrm{Na}^{+}$ion channel to remain in an open state for longer. Paradoxically, this cause shortening of the action potential duration, suggesting that, this compound can be used to minimize the length of the action potentials in tachycardia. However, KB130015 shows a significant promiscuity toward other ion channels involved in the cardiac action potential, and should therefore be investigated more carefully [46].

A number of mutations on SCN5A gene lead to dysregulation of $\mathrm{Na}_{\mathrm{v}} 1.5$ trafficking to the surface membrane resulting in reduced $\mathrm{Na}^{+}$ current amplitude [47]. In this case, use of $\mathrm{Na}_{\mathrm{v}} 1.5$ activators appears to be a promising prospective as they could compensate for the loss of $\mathrm{Na}^{+}$permeability and possibly restore cardiac function. Furthermore, it has been shown that, Mexiletine (a class IB antiarrhythmic drug) can improve membrane density of trafficking-deficient $\mathrm{Na}_{\mathrm{v}} 1.5$ channels suggesting that normal cardiac $\mathrm{Na}_{\mathrm{v}} 1.5$ function could be rescued by drugs that promote trafficking $[48,49]$. However, the effects of Mexiletine as $\mathrm{Na}_{\mathrm{v}} 1.5$ trafficking-deficient rescuer could be overruled by its properties as $\mathrm{Na}_{v} 1.5$ blocker and more critical studies need to be developed [50].

The slow inward $\mathrm{Na}^{+}$channel activator Ibutilitide is the only pure class III antiarrhythmic drug that has been approved for acute conversion of atrial fibrillation to normal sinus. This drug selectively enhances $\mathrm{I}_{\mathrm{NaL}}$ and results in prolongation of the cardiac action potential and refractory period [51].

\section{Pharmacology of the Cardiac Calcium Channel}

Similar to $\mathrm{Na}_{\mathrm{v}}$ channels, several human genes (CACNA1A through CACNA1I and CANCA1S) encode for multiple distinct voltagegated $\mathrm{Ca}^{2+}$ channels $\left(\mathrm{Ca}_{\mathrm{v}} 1.1-\mathrm{Ca}_{\mathrm{v}} 1.4 ; \mathrm{Ca}_{\mathrm{v}} 2.1-\mathrm{Ca}_{\mathrm{v}} 2.3 ; \mathrm{Ca}_{\mathrm{v}} 3.1-\mathrm{Ca}_{\mathrm{v}} 3.3\right)$. However, only $\mathrm{Ca}_{\mathrm{v}} 1.2$ channel (alias low-threshold $\mathrm{Ca}_{\mathrm{v}}$ channel; L-type) that is encoded by CACNA1C plays a role in the development of the cardiac action potential. Opening of the L-type calcium channel is essential to couple excitation to contraction as the inward $\mathrm{Ca}^{2+}$ currents initiate the release of $\mathrm{Ca}^{2+}$ from the sarcoplasmic reticulum by activating ryanodine receptors via a process called calcium-induced calcium release (CICR) [52]. This self-sustained increase in intracellular $\mathrm{Ca}^{2+}$ causes the plateau in the of the cardiac action potential shape and allows contraction of the cardiac myocytes [53].

\section{L-type $\mathrm{Ca}^{2+}$ channel blocker}

Although several L-type calcium channel blockers or gating inhibitors have been synthesized, only two members of the class IV antiarrhythmic drugs namely, verapamil and diltiazem, have been approved for clinical treatment of cardiac arrhythmia [54-57]. Similar to drugs targeting $\mathrm{Na}^{+}$channels, verapamil and diltiazem bind $\mathrm{Ca}_{\mathrm{v}} 1.2$ channel in its open state and exhibit "use dependence" with higher binding affinity at higher stimulation frequency [58]. Verapamil or diltiazem are primarily effective on tissues that present electrophysiological properties of a $\mathrm{Ca}^{2+}$ driven action potential (slow action potential). Therefore, it is mainly used to treat malfunctions of sinoatrial or atrioventricular nodes (e.g. paroxysmal supraventricular tachycardia), since their activity strongly depend upon calcium entry.

\section{L-type $\mathrm{Ca}^{2+}$ channel activator}

Reduced L-type $\mathrm{Ca}_{\mathrm{v}} 1.2$ density and regulation are thought to contribute to the disturbed $\mathrm{Ca}^{2+}$ handling during cardiac arrhythmia. For example, one of the frequent causes of action potential shortening during atrial fibrillation is a reduction of $\mathrm{Ca}_{\mathrm{v}} 1.2$ protein synthesis [59]. Therefore, stimulation of the L-type $\mathrm{Ca}^{2+}$ currents could be a possible approach to improve cardiac contractility in a failing heart [60]. Although not in large number, L-type $\mathrm{Ca}_{\mathrm{v}} 1.2$ channels activators have been used extensively to study function of the L-type currents. Dihydropyridines such as BAY K 8644 has proven to be excellent $\mathrm{Ca}_{\mathrm{V}} 1.2$ channel agonists in both animal model and isolated human cardiac myocytes. Interestingly, in these studies the BAY K 8644-dependent increase in inotropic effects on failing heart was reduced compared to a normal heart [61]. Nevertheless, use of adrenergic agonists partially rescued the limited effect of BAY K 8644 on failing heart.

One of the most common problems in using cardiotonic agents that acts on heart sarcolemma $\mathrm{Ca}^{2+}$ channels is calcium overload. The increased intracellular calcium, produced by for example glycosides, can cause arrhythmias. Thus, they have a low therapeutic index [62]. Interestingly, BAY K 8644 determines an increase of $\mathrm{Ca}^{2+}$ entry only at the beginning of the systole $(50 \mathrm{~ms}$; phase 2 ) with progressively smaller contribution during the plateau and has no effects on calcium entry during diastole. This phenomenon is probably due to the fast kinetics of recovery from blocking $\mathrm{Ca}_{\mathrm{v}} 1.2$. The small increase in $\mathrm{Ca}^{2+}$ entry produces no significant contribution in activating myofibrils but could certainly facilitate the $\mathrm{Ca}^{2+}$ release form sarcoplasm. Traditionally, arrhythmogenic disorders associated with deranged $\mathrm{Ca}^{2+}$ release from the sarcoplasmic reticulum have been associated with gain-of-function 
mutations on ryanodine receptors (RyR) that generates excessive $\mathrm{Ca}^{2+}$ leak from the intracellular store such as the sarcoplasmic reticulum. However, recent investigations started challenging this view as they report that a loss-of-function mutation on RyR type 2 (the most expressed in cardiac cells) is associated with sudden cardiac death [63]. This suggests that BAY K 8644-like drugs could be potentially used to treat cardiac arrhythmias associated with depressed sarcoplasmic $\mathrm{Ca}^{2+}$ release possibly due to loss-of-function mutations on ryanodine receptors. The rational for the use of $\mathrm{Ca}_{\mathrm{v}} 1.2$ activators as therapeutic approach to treat cardiac arrhythmias needs to accurately contemplate the possibility of severe side effects as besides the heart, $\mathrm{Ca}_{\mathrm{v}} 1.2$ plays a major role in several organs including brain and smooth muscles.

\section{Pharmacology of the Cardiac Potassium Channel}

The human genome comprises of circa 80 genes that encode for potassium channels among which many voltage-gated potassium channel (VGKC) are expressed in the heart.

The VGKC that play a major role in controlling the heart action potential belong to several sub-categories which comprise of members that are characterized by different biophysical parameters.

The Kv1.4, Kv4.2 and Kv4.3 are the main molecular contributor to the development of an outward $\mathrm{K}^{+}$current $\left(\mathrm{I}_{\mathrm{to}}\right)$ that counteracts the fast depolarization during phase $0[64,65]$.

During phase 3 of the cardiac action potential an outward $\mathrm{K}^{+}$ flux $\left(I_{K}\right)$ determines repolarization of the membrane and strongly contributes to restore resting membrane potential. Activity of several $\mathrm{K}^{+}$channels contribute to the development of the IK which can be divided in three distinct components: ultrarapid $\left(\mathrm{I}_{\mathrm{Kur}}\right)$ [66], rapid $\left(\mathrm{I}_{\mathrm{Kr}}\right)$ [67] and slow $\left(\mathrm{I}_{\mathrm{Ks}}\right)$ [68] component according to what cardiac cells are examined.

The $\mathrm{K}_{\mathrm{v}} 1.5$ channel is the major contributor for the $\mathrm{I}_{\mathrm{Kur}}$ and it is exclusively expressed in the atria (no $\mathrm{I}_{\mathrm{Kur}}$ current is detectable in the ventricle), while Kv11.1 (alias hERG1 channel) and Kv7.1 respectively control the $\mathrm{I}_{\mathrm{Kr}}$ and slow $\mathrm{I}_{\mathrm{Ks}}$ currents in several cardiac cells.

\section{$I_{\text {to }}$ current blockers}

Changes in Kv1.4, Kv4.2 or Kv4.3 potassium channels current densities can strongly alter activity of the L-type $\mathrm{Ca}^{2+}$ channels and therefore these $\mathrm{K}^{+}$channels can alter intracellular $\mathrm{Ca}^{2+}$ level during phase 2. For example, mutations on Kv4.3 channel that leads to increased $\mathrm{I}_{\text {to }}$ have been associated with Brugada syndrome [69]. Several class I antiarrhythmic drugs including quinidine and flecainide have been shown to inhibit $I_{\text {to }}$ current with similar potency in human and other mammalian heart and to be effective in controlling AF. However, due to concerning pro-arrhythmic effects and the development of better drugs, quinidine is mostly limited to treatment of vagally mediated AF.

\section{$\mathrm{I}_{\mathrm{Kur}}$ current blockers}

Class 1 and class III antiarrhythmic drugs have proven to be important tools but their action is limited to immediate treatment as they can produce fatal ventricular arrhythmias in the long-run. Studies indicate that this effect is due to the heterogeneity of the cardiac ventricular ion channel population and promiscuity of the drug in use. Therefore, targeting an ion channel with preferential expression in atrial tissue may provide a better therapeutic approach for the suppression of cardiac arrhythmias. Tests on the effects of several Kv1.5 blockers on heart function have revealed that these drugs do not alter repolarization of the cardiac action potential (normal QT interval) and restores the sinus rhythm during AF [70]. Interestingly, it has been shown that propafenone (class 1C antiarrhythmic) exhibits blocking activity on Kv1.5 channel suggesting that this event could contribute to the efficacy of propafenone in correcting paroxysmal AF [71,72]. Both gain and loss-of-function mutations in Kv1.5 channel have been found in patients affected by early-on-set lone AF which confirms the hypothesis that alteration of the $\mathrm{I}_{\text {Kur }}$ current can be associated with AF $[73,74]$. While no Kv1.5 channel activators have been identified yet, use of Kv1.5 blockers appears to be promising for treatment of some cardiac arrhythmias however, clinical data are still missing.

\section{$\mathrm{I}_{\mathrm{Kr}}$ current blockers}

The human Ether-a-go-go Related Gene $\underline{1}$ (hERG1) encodes for a 6 transmembrane a subunit of 1159 amino acids that assembles as tetramer on the surface membrane of several cardiac cells to form a voltage-gated potassium ion channel (Kv11.1). Activity of Kv11.1 plays a fundamental role during the repolarization phase of the cardiac action potential (phase 3 ).

Members of the methane sulfonanilide group of the class III antiarrhythmic drugs target Kv11.1 in a use-dependent manner as they preferentially bind the channel in its open state $[75,76]$. Consequently, they produce an elongation of the repolarization phase (phase 3 ) of the atrial and ventricular cardiac action potential and extend the refractory time. However, they can also exhibit reverse-use dependence on the action potential as they can affect other ion channels as well [77]. Therefore, although Kv11.1 blockers can exhibit notable differences, they are the commonly used drugs to prevent cardiac arrhythmias.

Amiodarone is the preferred drug for prevention of $\mathrm{AF}$ and it is under evaluation as a prophylactic therapy to prevent $\mathrm{AF}$ after cardiac surgery $[78,79]$. Although amiodarone is a Kv11.1 channel blocker, the incidence of ventricular fibrillation associated with amiodarone is very low compared to other class III anti-arrhythmic drugs. This is probably due to the inhibitory effect of amiodarone on $\mathrm{Ca}^{2+}$ channel activity that results in shortening of the duration of the action potential and therefore, counteracts the effects of amiodarone on Kv11.1 [80]. However, the inhibitory effects of amiodarone on $\mathrm{Ca}^{2+}$ permeability have been associated with a significantly higher incidence of bradycardia [81-83]. Other important side effects of amiodarone are not necessarily related to its action on the Kv11.1 channel, and include pulmonary toxicity, hepatotoxicity, reduced visual acuity, optic nerve injury, ataxia, sexual and gastrointestinal dysfunctions [84].

Dofetilide is a pure class III antiarrhythmic drug as it selectively blocks Kv11.1 and it is used with patients with AF [85]. However, the risk of drug-induced ventricular fibrillation is higher compared to amiodarone, although still rare [86].

Many therapeutic drugs used to treat different health conditions such as allergies, gastrointestinal or psychiatric disorders have been withdrawn from the market because of the severe inhibitory effects on Kv11.1 channel resulting in acquired-LQT2 (aLQT2). However, side effects of antiarrhythmic drugs targeting Kv11.1 channel can also result from the presence of the channel in extra heart tissues. For example, it has been shown that aLQT2 induced by some anti-epilectic drugs such as phenytoin or trimethadione [87] or even the class III antiarrhythmic almokalant strongly associate with teratogenesis $[88,89]$. In contrast, stimulation of Kv11.1 channel inhibits proliferation of breast cancer cells $[90,91]$. These events imply that aberrant changes of Kv11.1 electrical activity can play an important role also outside the heart.

\section{$\mathrm{I}_{\mathrm{Kr}}$ current activators}

Screening of unrelated individuals affected by LQT2 syndrome 
Citation: Perez-Neut M, Rao V, Haar L, Jones KW, Gentile S (2015) Current and Potential Antiarrhythmic Drugs Targeting Voltage-Gated Cardiac lon Channels. Cardiol Pharmacol 4: 139. doi:10.4172/2329-6607.1000139

Page 5 of 7

has revealed at least 290 loss-of-function and surprisingly one gain-offunction mutations on the hERG1 gene [92]. It is not understood why hERG1 gene is highly susceptible to genomic variation or drug targeting but this fact alone inspires the need to address the therapeutic value of potassium channel activators as anti-arrhythmic agents. The first Kv11.1 channel activator was discovered by David Rampe group who reported that the synthetic compound RPR260243 [93] significantly slowed deactivation of Kv11.1 which translates in an overall larger $\mathrm{K}^{+}$ outward current during phase 3 of the cardiac action potential resulting in a faster repolarization. Since then, other Kv11.1 channel activators have been discovered acting via diverse mechanisms. For example, NS1643 $[94,95]$ increases Kv11.1 currents by inhibiting inactivation of the channel. Interestingly, these Kv11.1 activators presented no severe effects on healthy animal hearts while they were able to rescue the effects of Kv11.1 blockers by shortening the QT interval. Furthermore, the non-steroidal anti-inflammatory drugs flufenamic and niflumic (which share high homology structure with NS1643) do not present any effects on heart function although they exhibit stimulatory effects on Kv11.1 channel activity [96]. This suggests the possibility that, Kv11.1 channel activator could be considered as therapeutic agents for the treatment of repolarization disorders in the heart including LQT syndrome.

\section{References}

1. Bezanilla F (2005) Voltage-gated ion channels. IEEE Trans Nanobioscience 4: $34-48$

2. Roden DM, Balser JR, George AL Jr, Anderson ME (2002) Cardiac ion channels. Annu Rev Physiol 64: 431-475.

3. Grant AO (2009) Cardiac ion channels. Circ Arrhythm Electrophysiol 2: 185194.

4. Bueno-Orovio A, Sanchez C, Pueyo E, Rodriguez B (2014) Na/K pump regulation of cardiac repolarization: insights from a systems biology approach. Pflugers Arch 466: 183-193.

5. Eisner DA, Sipido KR (2004) Sodium calcium exchange in the heart: necessity or luxury? Circ Res 95: 549-551.

6. Dhamoon AS, Jalife J (2005) The inward rectifier current (IK1) controls cardiac excitability and is involved in arrhythmogenesis. Heart Rhythm 2: 316-324.

7. DiFrancesco D, Borer JS (2007) The funny current: cellular basis for the control of heart rate. Drugs 67: 15-24.

8. Remme CA, Bezzina CR (2010) Sodium channel (dys)function and cardiac arrhythmias. Cardiovasc Ther 28: 287-294

9. Goldin AL (2003) Mechanisms of sodium channel inactivation. Curr Opin Neurobiol 132: 84-90.

10. Bezzina CR, Rook MB, Wilde AA (2001) Cardiac sodium channel and inherited arrhythmia syndromes. Cardiovasc Res 49: 257-271.

11. Strobel RE, Fisher JD, Katz G, Kim SG, Mercando AD (1990) Time dependence of ventricular refractory periods: implications for electrophysiologic protocols. J Am Coll Cardiol 15: 402-411.

12. Burton FL, Cobbe SM (2001) Dispersion of ventricular repolarization and refractory period. Cardiovasc Res 50: 10-23

13. Huang ZM, Prasad C, Britton FC, Ye LL, Hatton WJ, et al. (2009) Functional role of CLC-2 chloride inward rectifier channels in cardiac sinoatrial nodal pacemaker cells. J Mol Cell Cardiol 47: 121-132.

14. Hiraoka M, Kawano S, Hirano Y, Furukawa T (1998) Role of cardiac chloride currents in changes in action potential characteristics and arrhythmias. Cardiovasc Res 40: 23-33.

15. Duan D, Nattel S (1994) Properties of single outwardly rectifying $\mathrm{Cl}$ - channels in heart. Circ Res 75: 789-795.

16. Nerbonne JM, Kass RS (2005) Molecular physiology of cardiac repolarization Physiol Rev 85: 1205-1253.

17. Catterall WA, Swanson TM (2015) Structural Basis for Pharmacology of Voltage-Gated Sodium and Calcium Channels. Mol Pharmacol.
18. Catterall WA (2011) Voltage-gated calcium channels. Cold Spring Harb Perspect Biol 3: a003947.

19. Bers DM, Perez-Reyes E (1999) Ca channels in cardiac myocytes: structure and function in $\mathrm{Ca}$ influx and intracellular Ca release. Cardiovasc Res 42: 339360 .

20. Chockalingam P, Mizusawa Y, Wilde AA (2015) Channelopathies - emerging trends in the management of inherited arrhythmias. Indian Pacing Electrophysio J 15: 43-54.

21. Marsman RF, Tan HL, Bezzina CR (2014) Genetics of sudden cardiac death caused by ventricular arrhythmias. Nat Rev Cardiol 11: 96-111.

22. Wilde AA, Bezzina CR (2005) Genetics of cardiac arrhythmias. Heart 91: 1352 1358.

23. Bezzina CR, Wilde AA, Roden DM (2005) The molecular genetics of arrhythmias. Cardiovasc Res 67: 343-346.

24. Modell SM, Lehmann MH (2006) The long QT syndrome family of cardiac ion channelopathies: a HuGE review. Genet Med 8: 143-155

25. Roden DM (2000) Antiarrhythmic drugs: from mechanisms to clinical practice. Heart 84: 339-346.

26. Scholz H (1994) Classification and mechanism of action of antiarrhythmic drugs. Fundam Clin Pharmacol 8: 385-390.

27. Liu M, Yang KC, Dudley SC Jr (2014) Cardiac sodium channel mutations: why so many phenotypes? Nat Rev Cardiol 11: 607-615.

28. Adsit GS, Vaidyanathan R, Galler CM, Kyle JW, Makielski JC (2013) Channelopathies from mutations in the cardiac sodium channel protein complex. J Mol Cell Cardiol 61: 34-43.

29. Remme CA, Wilde AA, Bezzina CR (2008) Cardiac sodium channel overlap syndromes: different faces of SCN5A mutations. Trends Cardiovasc Med 18: $78-87$

30. Towbin JA, Ackerman MJ (2001) Cardiac sodium channel gene mutations and sudden infant death syndrome: confirmation of proof of concept? Circulation 104: 1092-1093.

31. Wang Q, Shen J, Li Z, Timothy K, Vincent GM, et al. (1995) Cardiac sodium channel mutations in patients with long QT syndrome, an inherited cardiac arrhythmia. Hum Mol Genet 4: 1603-1607.

32. Coppini R, Ferrantini C, Yao L, Fan P, Del Lungo M, et al. (2013) Late sodium current inhibition reverses electromechanical dysfunction in human hypertrophic cardiomyopathy. Circulation, 127, 575-584.

33. Amin AS, Tan HL, Wilde AA (2010) Cardiac ion channels in health and disease Heart Rhythm 7: 117-126.

34. Coppini R, Ferrantini C, Mazzoni L, Sartiani L, Olivotto I, et al. (2013) Regulation of intracellular $\mathrm{Na}(+)$ in health and disease: pathophysiological mechanisms and implications for treatment. Glob Cardiol Sci Pract 2013: 222-42.

35. Vaughan Williams EM. (1984) Subgroups of class 1 antiarrhythmic drugs. Eur Heart J 5: 96-98.

36. Milne JR, Hellestrand KJ, Bexton RS, Burnett PJ, et al. (1984) Class antiarrhythmic drugs--characteristic electrocardiographic differences when assessed by atrial and ventricular pacing. Eur Heart J 5: 99-107.

37. Stiell IG, Clement CM, Symington C, Perry JJ, Vaillancourt CA (2007) Emergency department use of intravenous procainamide for patients with acute atrial fibrillation or flutter. Acad Emerg Med 14: 1158-1164.

38. Grant AO, Dietz MA, Gilliam FR, Starmer CF (1989) Blockade of cardiac sodium channels by lidocaine. Single-channel analysis. Circ Res 65: 1247-1262.

39. Starmer CF, Nesterenko VV, Undrovinas AI, Grant AO, Rosenshtraukh LV (1991) Lidocaine blockade of continuously and transiently accessible sites in cardiac sodium channels. J Mol Cell Cardiol 23: 73-83.

40. Konzen G, Reichardt B, Hauswirth O (1990) Fast and slow blockade of sodium channels by flecainide in rabbit cardiac Purkinje fibres. Naunyn Schmiedebergs Arch Pharmacol 341: 565-76.

41. Razavi M(2005) Safe and effective pharmacologic management of arrhythmias Tex Heart Inst J 32: 209-211.

42. Edrich T, Wang SY, Wang GK (2005) State-dependent block of human cardiac hNav1.5 sodium channels by propafenone. J Membr Biol 207: 35-43. 
Citation: Perez-Neut M, Rao V, Haar L, Jones KW, Gentile S (2015) Current and Potential Antiarrhythmic Drugs Targeting Voltage-Gated Cardiac lon Channels. Cardiol Pharmacol 4: 139. doi:10.4172/2329-6607.1000139

43. Sakai R, Inoue D, Ishibashi K, Inoue M, Shirayama T, et al. (1995) Kinetics of frequency-dependent conduction delay by class I antiarrhythmic drugs in human atrium. J Cardiovasc Pharmacol 25: 953-960.

44. Comtois P, Sakabe M, Vigmond EJ, Munoz M, Texier A, et al. (2008) Mechanisms of atrial fibrillation termination by rapidly unbinding $\mathrm{Na}+$ channel blockers: insights from mathematical models and experimental correlates. Am J Physiol Heart Circ Physiol 295: H1489-504.

45. Shen W, Gill RM, Jones BD, Zhang JP, Corbly AK, et al. (2002) Combined inotropic and bradycardic effects of a sodium channel enhancer in conscious dogs with heart failure: a mechanism for improved myocardial efficiency compared with dobutamine. J Pharmacol Exp Ther 303: 673-80.

46. Macianskiene R, Viappiani S, Sipido KR, Mubagwa K (2003) Slowing of the inactivation of cardiac voltage-dependent sodium channels by the amiodarone derivative 2-methyl-3-(3,5-diiodo-4-carboxymethoxybenzyl)benzofuran (KB130015). J Pharmacol Exp Ther 304: 130-138.

47. Jagu B, Charpentier F, Toumaniantz G (2013) Identifying potential functional impact of mutations and polymorphisms: linking heart failure, increased risk of arrhythmias and sudden cardiac death. Front Physiol 4: 254.

48. Kang JX, Li Y, Leaf A (1997) Regulation of sodium channel gene expression by class I antiarrhythmic drugs and $\mathrm{n}-3$ polyunsaturated fatty acids in cultured neonatal rat cardiac myocytes. Proc Natl Acad Sci U S A 94: 2724-2728.

49. Abriel H (2007) Roles and regulation of the cardiac sodium channel $\mathrm{Na} \vee 1.5$ recent insights from experimental studies. Cardiovasc Res 76: 381-389.

50. Wang GK, Russell C, Wang SY (2004) Mexiletine block of wild-type and inactivation-deficient human skeletal muscle hNav1.4 $\mathrm{Na}+$ channels. J Physio 554: 621-633.

51. Roden DM (1996) Ibutilide and the treatment of atrial arrhythmias. A new drug-almost unheralded--is now available to US physicians. Circulation 94: 1499 1502.

52. Liang W (2008) Teaching calcium-induced calcium release in cardiomyocytes using a classic paper by Fabiato. Adv Physiol Educ 32: 1-10.

53. Smyth JW, Shaw RM (2010) Forward trafficking of ion channels: what the clinician needs to know. Heart Rhythm 7: 1135-1140.

54. Elkayam U (1998) Calcium channel blockers in heart failure. Cardiology 89: $38-46$

55. Pieper JA (1996) Evolving role of calcium channel blockers in heart failure Pharmacotherapy 16: 43S-49S

56. Heywood JT (1995) Calcium channel blockers for heart rate control in atria fibrillation complicated by congestive heart failure. Can J Cardiol 11: 823-826.

57. Su J, Renaud N, Carayon A, Crozatier B, Hittinger L (1994) Effects of the calcium channel blockers, diltiazem and Ro 40-5967, on systemic haemodynamics and plasma noradrenaline levels in conscious dogs with pacing-induced heart failure. Br J Pharmacol 113: 395-402.

58. Frank GB (1986) A pharmacological explanation of the use-dependency of the verapamil (and D-600) block of slow calcium channels. J Pharmacol Exp Ther 236: 505-511.

59. Brundel BJ, Ausma J, van Gelder IC, Van der Want JJ, van Gilst WH, et al (2002) Activation of proteolysis by calpains and structural changes in human paroxysmal and persistent atrial fibrillation. Cardiovasc Res 54: 380-389.

60. Seebohm G (2005) Activators of cation channels: potential in treatment of channelopathies. Mol Pharmacol 67: 585-588.

61. Chen X, Zhang X, Harris DM, Piacentino V 3rd, Berretta RM, et al. (2008) Reduced effects of BAY K 8644 on L-type Ca2+ current in failing human cardiac myocytes are related to abnormal adrenergic regulation. Am J Physio Heart Circ Physiol 294: H2257-2267.

62. Thomas G, Chung M, Cohen CJ (1985) A dihydropyridine (Bay k 8644) that enhances calcium currents in guinea pig and calf myocardial cells. A new type of positive inotropic agent. Circ Res 56: 87-96

63. Scoote M, Williams AJ (2002) The cardiac ryanodine receptor (calcium release channel): emerging role in heart failure and arrhythmia pathogenesis. Cardiovasc Res 56: 359-72.

64. Niwa N, Nerbonne JM (2010) Molecular determinants of cardiac transient outward potassium current (I(to)) expression and regulation. J Mol Cell Cardio 48: $12-25$
65. Oudit GY, Kassiri Z, Sah R, Ramirez RJ, Zobel C, Backx PH (2001) The molecular physiology of the cardiac transient outward potassium current (I(to)) in normal and diseased myocardium. J Mol Cell Cardiol 33: 851-872.

66. Nattel S, Yue L, Wang Z (1999) Cardiac ultrarapid delayed rectifiers: a nove potassium current family of functional similarity and molecular diversity. Cell Physiol Biochem 9: 217-226.

67. Mitcheson JS, Sanguinetti MC (1999) Biophysical properties and molecular basis of cardiac rapid and slow delayed rectifier potassium channels. Cell Physiol Biochem 9: 201-216.

68. Jost N, Papp JG, Varro A (2007) Slow delayed rectifier potassium current (IKs) and the repolarization reserve. Ann Noninvasive Electrocardiol 12: 64-78.

69. Giudicessi JR, Ye D, Tester DJ, Crotti L, Mugione A, et al. (2011) Transient outward current (I(to)) gain-of-function mutations in the KCND3-encoded Kv4.3 potassium channel and Brugada syndrome. Heart Rhythm 8: 1024-1032.

70. Shah M, Akar FG, Tomaselli GF (2005) Molecular basis of arrhythmias. Circulation 112: 2517-2529.

71. Delpon E, Valenzuela C, Perez O, Casis O, Tamargo J (1995) Propafenone preferentially blocks the rapidly activating component of delayed rectifier $\mathrm{K}+$ current in guinea pig ventricular myocytes. Voltage-independent and timedependent block of the slowly activating component. Circ Res 76: 223-35.

72. Ravens U, Poulet C, Wettwer E, Knaut M (2013) Atrial selectivity of antiarrhythmic drugs. J Physiol 591: 4087-4097.

73. Nielsen JB, Bentzen BH, Olesen MS, David JP, Olesen SP, et al. (2013) Gainof-function mutations in potassium channel subunit KCNE2 associated with early-onset lone atrial fibrillation. Biomark Med 8: 557-570.

74. Olson TM, Alekseev AE, Liu XK, Park S, Zingman LV, et al. (2006) Kv1.5 channelopathy due to KCNA5 loss-of-function mutation causes human atrial fibrillation. Hum Mol Genet 15: 2185-2191.

75. Mitcheson JS, Chen J, Lin M, Culberson C, Sanguinetti MC (2000) A structura basis for drug-induced long QT syndrome. Proc Natl Acad Sci U S A 97: 1232912333.

76. Numaguchi H, Mullins FM, Johnson JP, Johns DC, Po SS, et al. (2000) Probing the interaction between inactivation gating and Dd-sotalol block of HERG. Circ Res 87: 1012-1018.

77. Tamargo J, Caballero R, Gomez R, Valenzuela C, Delpon E (2004) Pharmacology of cardiac potassium channels. Cardiovasc Res 62: 9-33.

78. Bagshaw SM, Galbraith PD, Mitchell LB, Sauve R, Exner DV, et al. (2006) Prophylactic amiodarone for prevention of atrial fibrillation after cardiac surgery: a meta-analysis. Ann Thorac Surg 82: 1927-1937.

79. Van Herendael H, Dorian $P$ (2010) Amiodarone for the treatment and prevention of ventricular fibrillation and ventricular tachycardia. Vasc Health Risk Manag 6: 465-472.

80. Chen F, Wetzel GT, Cho P, Friedman WF, Klitzner TS (1996) Mechanisms of amiodarone-induced inhibition of $\mathrm{Ca} 2+$ current in isolated neonatal rabbit ventricular myocytes. J Investig Med 44: 583-589.

81. Brodine WN, De Santis J (1982) Sinus arrest during treatment with amiodarone. Br Med J (Clin Res Ed) 285: 1047.

82. McGovern B, Garan H, Ruskin JN (1982) Sinus arrest during treatment with amiodarone. Br Med J (Clin Res Ed) 284: 1120

83. Hofmann R, Leisch F (1995) [Symptomatic bradycardia with amiodarone in patients with pre-existing conduction disorders]. Wien Klin Wochenschr 107 640-644.

84. Hilleman D, Miller MA, Parker R, Doering P, Pieper JA (1998) Optima management of amiodarone therapy: efficacy and side effects. Pharmacotherapy 18: 138S-145S.

85. Pedersen OD, Bagger H, Keller N, Marchant B, Kober L, et al. (2001) Efficacy of dofetilide in the treatment of atrial fibrillation-flutter in patients with reduced left ventricular function: Danish investigations of arrhythmia and mortality on dofetilide (diamond) substudy. Circulation 104: 292-296.

86. Lauer MR (2001) Dofetilide: is the treatment worse than the disease? J Am Coll Cardiol 37: 1106-1110.

87. Danielsson BR, Lansdell K, Patmore L, Tomson T (2003) Phenytoin and phenobarbital inhibit human HERG potassium channels. Epilepsy Res 55: 147 157. 
Citation: Perez-Neut M, Rao V, Haar L, Jones KW, Gentile S (2015) Current and Potential Antiarrhythmic Drugs Targeting Voltage-Gated Cardiac lon Channels. Cardiol Pharmacol 4: 139. doi:10.4172/2329-6607.1000139

88. Azarbayjani F, Danielsson BR (2002) Embryonic arrhythmia by inhibition of HERG channels: a common hypoxia-related teratogenic mechanism for antiepileptic drugs? Epilepsia 43: 457-468.

89. Babcock JJ, Li M (2013) hERG channel function: beyond long QT. Acta Pharmacol Sin 34: 329-335.

90. Perez-Neut M, Shum A, Cuevas BD, Miller R, Gentile S (2015) Stimulation of hERG1 channel activity promotes a calcium-dependent degradation of cyclin E2, but not cyclin E1, in breast cancer cells. Oncotarget, 6, 1631-1639.

91. Lansu K, Gentile S (2013) Potassium channel activation inhibits proliferation of breast cancer cells by activating a senescence program. Cell Death Dis 4: e652.

92. Hedley PL, Jorgensen $P$, Schlamowitz $S$, Wangari R, Moolman-Smook J, et al. (2009) The genetic basis of long QT and short QT syndromes: a mutation update. Hum Mutat 30:1486-1511.
93. Kang J, Chen XL, Wang H, Ji J, Cheng H, et al. (2005) Discovery of a small molecule activator of the human ether-a-go-go-related gene (HERG) cardiac $\mathrm{K}+$ channel. Mol Pharmacol 67: 827-836.

94. Grunnet M, Abbruzzese J, Sachse FB, Sanguinetti MC (2011) Molecula determinants of human ether-a-go-go-related gene 1 (hERG1) K+ channel activation by NS1643. Mol Pharmacol 79: 1-9.

95. Hansen RS, Diness TG, Christ T, Demnitz J, Ravens U, et al. (2006) Activation of human ether-a-go-go-related gene potassium channels by the diphenylurea 1, 3-bis-(2-hydroxy-5-trifluoromethyl-phenyl)-urea (NS1643). Mol Pharmacol 69: 266-277.

96. Malykhina AP, Shoeb F, Akbarali HI (2002) Fenamate-induced enhancement of heterologously expressed HERG currents in Xenopus oocytes. Eur J Pharmacol 452: 269-277. 